\title{
Landasan Sikap Oposisi Front Pembela Islam (FPI) Terhadap Pemerintahan Joko Widodo Tahun 2014-2020
}

\author{
Reni Rentika Waty* \\ Universitas Indonesia, Depok \\ *Email: renirentikaw@gmail.com
}

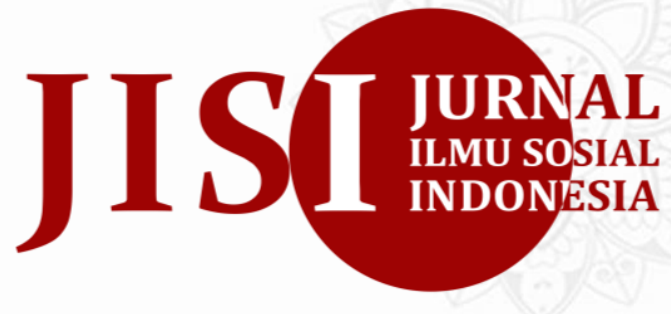

p-ISSN: 2808-9529 (Printed)

e-ISSN: 2808-8816 (Online)

Jurnal Ilmu Sosial Indonesia (JISI)

http://journal.uinjkt.ac.id/index.php/jisi

VOL. 2, NO. 2 (2021)

Page: $71-84$

Recommended Citation:

Waty, R. (2021). Landasan Sikap Oposisi

Front Pembela Islam (FPI) Terhadap

Pemerintahan Joko Widodo Tahun 20142020. Jurnal Ilmu Sosial Indonesia (JISI), 2(2), 71-84.

doi:https://doi.org/10.15408/jisi.v2i2.22726

Available at:

http://journal.uinjkt.ac.id/index.php/jisi/arti cle/view/22726

Article History:

Received 07 October 2021

Accepted 05 November 2021

Available online 28 December 2021

* Corresponding Author

\begin{abstract}
FPI (Islamic Defenders Front) is a mass organization that has consistently became the opposition since the reformation. However, during the Joko Widodo's (Jokowi) reign, the opposition stance of FPI was more dominant. By the though of Habib Rizieq Syihab as founder of FPI about democracy, as well as utilizing qualitative methods, this study aims to analyze the reasons of FPI's positioning as an opposition to the Jokowi government. This study finds there are two factors that become the basis of FPI's opposition namely ideological and political. Ideologically, FPI's opposition is caused by what is believe as democrazy system, economic democrazy and legal democracy that occurred in Indonesia. In addition, the political factor is caused background was caused by various conflicts between FPI and the Jokowi government, namely the criminalization of ulama, the polemic of HRS's return to Indonesia, the shooting of the FPI Laskar, the disbandment of the FPI and the arrest of FPI members.
\end{abstract}

Keywords: FPI, democrazy, opposition, Jokowi's government.

Abstrak. FPI (Front Pembela Islam) merupakan organisasi kemasyarakatan yang secara konsisten menempatkan diri sebagai oposisi sejak reformasi. Namun, pada masa pemerintahan Joko Widodo (Jokowi) sikap oposisi FPI lebih dominan dibandingkan dengan masa pemerintahan sebelumnya. Dengan landasan berpikir Habib Rizieq Syihab selaku pendiri FPI terkait demokrasi, serta metode kualitatif, penelitian ini ingin melihat alasan FPI memposisikan diri sebagai oposisi terhadap pemerintahan Jokowi. Hasil penelitian ini memperlihatkan bahwa landasan sikap oposisi FPI dibedakan menjadi dua latar belakang, yakni ideologis dan politis. Secara ideologis, sikap oposisi FPI disebabkan oleh democrazy sistem, democrazy ekonomi dan democrazy hukum yang terjadi di Indonesia. Kemudian, latar belakang politis diakibatkan oleh berbagai konflik antara FPI dengan pemerintahan Jokowi, yaitu kriminalisasi ulama, polemik kepulangan HRS ke Indonesia, penembakan Laskar FPI, pembubaran FPI dan penangkapan anggota FPI.

Kata Kunci: FPI, demokrasi, oposisi, pemerintahan Jokowi. 


\section{PENDAHULUAN}

Pasca Orde Baru banyak Organisasi Kemasyarakatan (Ormas) Islam yang bermunculan, diantaranya adalah Organisasi Tarbiyah (sekarang menjadi Partai Keadilan Sejahtera), Hizbut Tahrir Indonesia (HTI), Front Pembela Islam (FPI), dan Laskar Jihad (Rahmat, 2007, hal. 135). Kemunculan berbagai Ormas Islam ini diakibatkan oleh terbukanya ruang gerak dan melemahnya kontrol pemerintah terhadap Ormas Islam (Zastrow, 2013, hal. 2). Hal yang melatarbelakangi berdirinya FPI adalah maraknya kezaliman dan kemaksiatan di tengah masyarakat yang dianggap dapat menimbulkan banyak musibah.

FPI pertama kali dicetuskan di Petamburan dan dideklarasikan secara terbuka di Pondok Pesantren Al Umm, Ciputat pada 25 Rabi'uts Tsani 1419 atau bertepatan dengan 17 Agustus 1998. Tokoh yang mendeklarasikan diantaranya adalah (FaktaKini, 2019): 1) Habib Rizieq Syihab (HRS), 2) Syekh Misbahul Anam At-Tijany, 3) KH. Cecep Bustomi, 4) KH. Syafi'i Ahmad, 5) Habib Idrus bin Alwi Jamalullail, 6) KH. Munahar Muhtar, 7) KH. Baydowi, 8) KH. Damanhuri, 9) Habib Salim bin Umar Al Hamid, 10) KH. Salim Nasir. Para tokoh pendiri FPI ini berlatar belakang ulama pesantren dan pimpinan majelis ta'lim.

Mengutip dari Ketetapan Musyawarah Nasional I FPI, tujuan pembentukan FPI adalah karena adanya penderitaan panjang yang dialami umat Islam Indonesia karena lemahnya kontrol sosial dan akibat dari banyaknya pelanggaran HAM yang dilakukan oleh oknum penguasa (saat Orde Baru). Pembentukan FPI juga di dorong oleh adanya kewajiban umat muslim untuk menjaga dan mempertahankan, membela harkat dan martabat Islam dan umatnya (Syihab, 2008, hal. 589). Sehingga FPI berupaya untuk: 1) mengembalikan umat Islam pada fitrahnya; 2) mendidik ummat Islam agar bisa hidup mandiri, sejahtera dan Islami; 3) terciptanya bahasa persamaan pandangan dalam indahnya Islam yang kamil; 4) menetapkan syari'at Islam secara kaffah; 5) menumbuhkan kembangkan semangat dan kemapuan anggota untuk menguasai, memanfaatkan serta mengikuti perkembangan ilmu pengetahuan dan teknologi bagi kesejahteraan umat.

Selama perkembangannya FPI menjadi salah satu Ormas Islam yang memiliki eksistensi dan pengaruh. FPI mengklaim bahwa karakter gerakannya adalah tradisionalis moderat. Tradisional karena mereka berbaur dengan masyarakat, sehingga tidak eksklusif. Kemudian, pada sikap tradisional terdapat sifat moderat yakni tidak memaksakan dengan ibadah yang memberatkan. Habib Rizieq Syihab (HRS) selaku pendiri FPI menyebutkan bahwa FPI membangun loyalitas terhadap Islam, bukan terhadap salah satu figur maupun organisasi. Selama figur dan organisasi berjalan sesuai syari'at Islam maka wajib untuk dipatuhi (Syihab, 2008, hal. 225-226). Sehingga, sebagai Ormas Islam FPI menunjukan kekuatannya sebagai kelompok penekan (oposisi) terhadap aktor politik yang dianggap tidak "pro" terhadap Islam. Salah satu hal yang dilakukan adalah dengan tidak memberikan dukungan politik terhadap kandidat calon yang dianggap tidak sesuai dengan syariat Islam.

Sebagai oposisi, FPI masif melakukan sweeping (menutup tempat maksiat) dan demostransi terkait dengan hal yang dianggap tidak relevan dengan syariat Islam. Sikap oposisional FPI sebagai kelompok penekan dapat dilihat melalui konflik yang terjadi antara FPI dan rezim pemerintahan. Pada masa pemerintahan Joko Widodo (Jokowi) yang dimulai pada 2014, gerakan dan sikap oposisional FPI berbeda dengan sikap FPI pada pemerintahan yang ada sebelumnya. Gerakan pemberantasan kemaksiatan yang dilakukan FPI pada pemerintahan Jokowi tidak lagi terfokus pada sweeping, tetapi FPI lebih banyak terlibat pada politik praktis seperti demonstrasi dan pemberian dukungan politik. Meskipun gerakan sweeping tidak sepenuhnya hilang di Era Jokowi, namun intensitasnya jauh berkurang. Tujuannya adalah untuk menerapkan syari'at Islam dan meminimalisir kemaksiatan yang berkembang di masyarakat.

HRS dalam bukunya (Syihab, 2013 mengatakan bahwa demokrasi telah menciptakan sistem yang korup di seluruh dunia. Demokrasi adalah monster yang telah menciptakan diktator kelas dunia, yang juga menjadi penyebab terjadinya perpecahan di berbagai negara akibat dari adanya perebutan kekuasaan. Atas alasan tersebut HRS selanjutnya menyebut demokrasi menjadi "democrazy".

HRS membagi democrazy menjadi lima. Pertama, democrazy sistem. Pada poin ini demokrasi dibagi menjadi (Syihab, 2013, hal. 109-110): 1) democrazy voting, yakni sistem yang di mana setiap orang dapat menjadi pemimpin meskipun tidak memiliki kapabilitas. Pemimpin terpilih hanya karena mendapat suara terbanyak. Hal ini dianalogikan oleh HRS dengan "monyet boleh jadi presiden asal disetujui suara terbanyak"; 2) democrazy politik, di mana suara setiap orang dianggap setara. HRS mengatakan bahwa adanya kesamaan antara hak dan kewajiban antara ulama dan pelacur, begitu juga dengan hak suara. Kemudian, dengan musyawarah segala sesuatu yang haram bisa berubah menjadi halal asalkan disetujui oleh suara mayoritas; 3) democrazy kebhinnekaan, dengan mengatasnamakan kebhinnekaan hal yang buruk dapat diterima dengan baik, sebaliknya kebaikan dapat dimaknai menjadi buruk. Contohnya adalah ketika aliran sesat dianggap sebagai 
kebebasan beragama dan penodaan agama dianggap sebagai kebebasan berekspresi, kemudian membela agama dengan tegas dianggap radikal.

Kedua, democrazy ekonomi. Poin ini dibagi menjadi dua (Syihab, 2013, hal. 110-111): 1) democrazy kesenjangan, demokrasi menciptakan sebuah sistem ekonomi dimana orang kaya akan semakin kaya dan orang miskin akan semakin miskin. Hal ini disebabkan oleh tingginya pajak dan sulitnya mencari pekerjaan; 2) democrazy pemiskinan, dimana negara memiliki sumber daya alam tetapi masih mengandalkan impor dari negara lain, akhirnya rakyat harus membayar mahal untuk membeli barang impor tersebut.

Ketiga, democrazy hukum. Poin ini dibagi menjadi (Syihab, 2013, hal. 111): 1) democrazy keadilan, tidak ada hukuman yang setimpal dan adil atas suatu kesalahan. HRS membandingkan hukum di Indonesia dengan di Arab, ketika orang mencuri dipotong tangan, sementara di Indonesia koruptor dipotong masa tahanannya; 2) democrazy diskriminasi, terjadinya diskriminasi terhadap sesuatu yang benar dan pembenaran terhadap sesuatu yang salah. Contohnya adalah ketika Ormas melakukan salah maka organisasinya yang salah, tetapi ketika partai politik atau pejabat yang bersalah maka itu dianggap sebagai kesalahan oknum saja.

Keempat, democrazy sosial budaya. Poin ini dibagi menjadi (Syihab, 2013, hal. 112-113): 1) democrazy gaya hidup, pada konteks ini contoh yang dijelaskan HRS adalah ketika seorang berpoligami dianggap sesuatu yang menjijikan, sedangkan perselingkuhan dibiarkan dan dijadikan sebagai gaya hidup; 2) democrazy adat dan tradisi, contohnya ketika perempuan berjilbab dianggap meresahkan sedangkan yang telanjang dijadikan sebagai adat yang menyenangkan; 3) democrazy seni dan budaya, ketika budaya yang menampilkan perempuan dengan busana terbuka dilindungi dengan dalih perlestarian budaya.

Kelima, democrazy trans-nasional yakni kondisi ketika negara barat menyerang negara muslim dianggap sebuah kebenaran. Sedangkan ketika negara muslim tersebut melakukan perjuangan untuk membela diri, maka tindakan tersebut dianggap sebagai kesalahan dan disebut sebagai teroris. Contoh kasus yang disebutkan HRS adalah kejahatan Amerika Serikat terhadap Iraq dan Afganistan, Israel di Palestina, Cina di Xinjiang, Myanmar di Rohingya, Filipina di Mindanau, Thailand di Patani dan Rusia di Checnya (Syihab, 2013, hal. 113).

Jika melihat pada penelitian sebelumnya, telah banyak yang menjelaskan mengenai penyebab lahirnya organisasi Islam radikal yang memiliki kecenderungan beroposisi terhadap pemerintah. Nurjannah (2013, hal. 17) pada penelitiannya menjelaskan penyebab lahirnya organisasi Islam radikal dengan sangat rinci. Munculnya radikalisme dalam Islam dilatarbelakangi oleh faktor-faktor yang meliputi: 1) ekspresi dari ajaran mengenai pembaruan; 2) dampak dari pemikiran Ikhwanul Muslim dan Jamaati Islami; 3) keterbelakangan ekonomi, ilmu pengetahuan dan teknologi; 4) ketidakadilan terhadap masyarakat muslim; 5) dampak dari ajaran Islam tentang dakwah, amar makruf nahi mungkar, jihad, dan semacamnya yang ditafsir ekslusif; 6) semangat Arabisme yang berhasil membangun kebencian terhadap negaranegara Barat; 7) reaksi revolusioner terhadap modernisasi dan globalisasi; 8) faktor kepribadian, misalnya mental teroris. Pada konteks radikalisme di Indonesia, Nurjannah menjelaskan kemunculannya dipicu oleh krisis multidimensi di era Orde Baru di penghujung masa kekuasaan Presiden Suharto, yakni represi politik, ketimpangan ekonomi, runtuhnya moralitas, dan ketimpangan sosial.

Sebagaimana yang telah dijelaskan Nurjannah, penulis melihat ada perbedaan dan kesamaan pandangan dalam konteks radikalisme FPI. Penulis melihat bahwa ada dua faktor yang mempengaruhi radikalime pemikiran FPI: Pertama, faktor internal yakni berasal dari organisasi yang melihat terjadinya penyimpangan terhadap norma-norma agama. Sama halnya dengan penjelasan Zuhri (2017) dan Zada (2002), menjelaskan bahwa radikalisme yang melekat pada Ormas Islam khususnya FPI adalah suatu reaksi yang muncul dari suatu kondisi yang mereka anggap tidak sesuai dengan syariat Islam yang orientasi pada amar makruf nahi mungkar. Kondisi tersebut adalah adanya keterbelakangan ekonomi, ilmu pengetahuan dan teknologi seperti yang disebutkan oleh Nurjannah (2013). Namun, disini penulis melihat bahwa kondisi politik yang tidak stabil juga sangat mempengaruhi munculnya pemikiran dan gerakan radikalisme Ormas Islam.

Kedua, faktor eksternal yakni masuknya doktrin untuk menolak sistem sekular barat dan mendorong umat Islam untuk ber-jihad untuk menegakan syariat Islam. Dalam hal ini Nurjannah (2013) juga menjelaskan bahwa semangat Arabisme telah membangun kebencian terhadap negara-negara Barat, sehingga Ormas tersebut melakukan tindakan radikal dalam menegakan syariat Islam. Jika Wahid melihat bahwa sikap radikal berasal dari lemahnya pengetahuan tentang syariah, realitas, sunnatullah dan kehidupan, dalam hal ini penulis melihat sebaliknya. Penulis melihat, FPI memiliki pemahaman mengenai syariat Islam yang mengacu pada orientasi amar makruf nahi mungkar. FPI juga jeli atas realitas yang terjadi sehingga ia memposisikan diri sebagai Ormas yang beroposisi terhadap pemerintah.

Berdasarkan kajian-kajian di atas, dapat dilihat bahwa sikap oposisional FPI sebagai Ormas Islam radikal menunjukkan eksistensi dan 
kekuatannya terhadap pemerintahan yang dianggap tidak aspiratif terhadap Islam (Zada, 2002, hal. 8). Keinginan yang kuat untuk mewujudkan suatu sistem politik Islam membuat FPI bertentangan dengan pemerintahan dan sistem politik Indonesia. Mengulas pendapat Yamin (2018), Heryanto (2019) dan Jurdi (2016), mereka melihat bahwa sebagai kelompok penekan, sikap FPI cukup ekstrim dan tegas. Seringkali sikap ini mengarah pada kekerasan dan menyimpang. Lebih lanjut dari semua penelitian di atas, menjelaskan bahwa sikap oposisi yang dilakukan FPI sebagai kelompok penekan adalah penerapan konsep amal ma'ruf nahi munkar. Dalam hal ini penulis memandang bahwa sikap oposisi FPI terbentuk atas kepentingan politik yang didasari oleh kepentingan ideologis.

Penulis melihat bahwa belum banyak peneliti yang mengkaji mengenai sikap oposisional FPI. Para peneliti hanya menafsirkan alasan dari sikap radikalisme FPI hanya terfokus pada kondisi sosial. Mereka tidak melihat pada situasi dan kondisi politik yang menjadi salah satu pemicu timbulnya radikalisme yang mengarah pada sikap oposisional. Mereka juga tidak membahas mengenai aspek ideologis FPI sebagai hal yang mempengaruhi sikap oposisi FPI terhadap pemerintah. Pemerintahan Jokowi dipilih sebagai objek kajian karena, penulis melihat adanya intensitas gerakan oposisi FPI terhadap pemerintahan Jokowi dibandingkan dengan rezim penguasa sebelumnya.

Atas dasar latar belakang tersebut, penelitian ini fokus pada permasalahan tentang latar belakang sikap oposisi FPI pada masa pemerintahan Jokowi tahun 2014-2020. Tujuan penelitian ini secara umum adalah mengetahui tentang sikap oposisi yang dilakukan FPI terhadap pemerintahan Joko Widodo, kemudian secara khusus penelitian ini bertujuan untuk menginvestigasi alasan FPI memposisikan diri sebagai oposisi di masa pemerintahan Joko Widodo.

\section{METODOLOGI}

Penelitian ini menggunakan metode kualitatif, yakni metode penelitian yang digunakan untuk mendeskripiskan dan menganalisis suatu fenomena, peristiwa, sikap, aktivitas sosial, persepsi, ataupun pemikiran baik individu maupun kelompok (Sukmadinata, 2012, hal. 60). Dalam penelitian ini penulis menggunakan pendekatan studi kasus (case study) dimana peneliti mengembangkan atas suatu kasus, peristiwa, aktivitas atau suatu proses. Kasus tersebut dibatasi oleh waktu dan aktivitas dan penulis mengumpulkan informasi secara lengkap dengan prosedur pengumpulan data berdasarkan waktu yang telah ditentukan (Creswell, 2017, hal. 19). Penulis mencermati sikap oposisi FPI sebagai suatu peristiwa, aktivitas, dan proses yang dibatasi oleh waktu, yakni pada masa pemerintahan Jokowi pada tahun 20142020.

Berdasarkan studi kasus yang diteliti oleh penulis, untuk menganalisis data penelitian penulis menggunakan model analisis interaktif model Miles dan Huberman (2014, hal. 12-14) dengan cara reduksi data, kemudian dilanjutkan dengan penyajian data dan penarikan kesimpulan. Penelitian ini menggunakan empat jenis strategi dalam prosedur pengumpulan data, yakni: Pertama, wawancara kualitatif. Peneliti melakukan face-to-face interview dengan Syahrozi selaku Ketua Sekretariat FPI, Irbabul Lubab selaku Wakil Sekretaris Bidang Penagakan Khilafah FPI, Slamet Ma'arif selaku Ketua Persatuan Alumni 212. Kedua, Dokumen-dokumen kualitatif berupa dokumen publik seperti koran, majalah atau laporan, kemudian dokumen privat seperti surat, email dan lainnya. Data tersebut bersumber dari media cetak dan elektronik berupa rilis dokumen resmi/arsip FPI, buku, jurnal, artikel berita, hasil penelitian tesis dan disertasi. Ketiga, materi audio dan visual, data bisa berupa foto, videotape dan arsip digital yang diambil dari portal berita online, website resmi, dan platform media sosial (Youtube, Instagram, dan Twitter).

\section{TEMUAN DAN PEMBAHASAN}

\section{Latar Belakang Ideologis}

FPI sebagai Ormas Islam sangat menjunjung tinggi nilai Islam yang mereka pahami. FPI melihat adanya urgensi untuk penerapan syariat Islam di Indonesia. Hal ini tidak terlepas dari pandangan FPI yang menganggap bahwa sistem demokrasi membawa efek buruk dan sumber masalah yang nyata. HRS dalam bukunya yang berjudul "Hancurkan Liberalisme, Tegakan Syariat Islam" mengatakan bahwa demokrasi telah menciptakan sistem yang korup. Demokrasi telah menciptakan diktator, yang juga menjadi penyebab perpecahan akibat dari adanya perebutan kekuasaan. Sehingga HRS menyebut demokrasi menjadi "democrazy".

HRS memandang bahwa syariat Islam dan demokrasi memiliki perbedaan yang sangat mendasar dan saling bertentangan. Sistem Islam bersifat illahiyah, bersumber dari Allah SWT yang bersifat sempurna. Demokrasi berasal dari akal manusia yang memiliki keterbatasan sehingga tidak sempurna. Hukum yang diterapkan pada syariat Islam berasal dari Allah SWT melalui Al Qur'an dan Sunnah, sedangkan demokrasi berdasarkan suara terbanyak. Di dalam sistem Islam suara ulama tidak setara dengan suara orang awam, sedangkan pada sistem demokrasi setiap orang memiliki hak suara yang sama. HRS membagi democrazy yang terjadi di Indonesia, yang penulis jabarkan seperti di bawah ini: 


\subsection{Democrazy Sistem}

Democrazy sistem terbagi menjadi democrazy voting, democrazy politik dan democrazy kebhinnekaan (Syihab, 2013, hal. 109-110). Pertama, democrazy voting. Suatu mekanisme di mana setiap orang dapat menjadi pemimpin meskipun tidak memiliki kapabilitas. Pemimpin terpilih hanya karena mendapat suara terbanyak. Hal ini dianalogikan oleh HRS dengan "monyet boleh jadi presiden asal disetujui suara terbanyak". Pernyataan yang sama juga dikemukakan oleh Ust. Irbabul Lubab, bahwa dalam demokrasi setiap orang memiliki nilai suara yang sama.

Kedua, democrazy politik di mana suara setiap orang dianggap setara. HRS mengatakan bahwa adanya kesamaan antara hak dan kewajiban antara ulama dan pelacur, begitu juga dengan hak suara. Kemudian, dengan musyawarah segala sesuatu yang haram bisa berubah menjadi halal asalkan disetujui oleh suara mayoritas. Sebagaimana anggapan tersebut, HRS juga menganggap bahwa musyawarah mufakat pada sistem demokrasi hanya omong kosong, sebab kesepakatan diambil dari suara terbanyak bukan melalui musyawarah mufakat. Penggunaan suara terbanyak dalam pengambilan keputusan kebijakan dapat menghasilkan kebijakan yang salah.

Ketiga, democrazy kebhinnekaan. Mengatasnamakan ke-bhinnekaan hal yang buruk dapat diterima dengan baik, sebaliknya kebaikan dapat dimaknai menjadi buruk. HRS mencontohkan ketika aliran sesat dianggap sebagai kebebasan beragama dan penodaan agama dianggap sebagai kebebasan berekspresi, kemudian membela agama dengan tegas dianggap radikal. Dalam poin ini, salah satu contoh kasus yang disorot oleh FPI adalah penodaan agama yang dilakukan oleh Ade Armando Dosen Universitas Indonesia. Sebagaimana yang dikemukakan oleh Slamet Ma'arif:

"Kita melihat bahwa periode pertama pemerintahan Jokowi waktu itu ada gejala Islamophobia, kita melihat banyak ulama-ulama yang mengkritisi kemudian harus dipidanakan, sementara penista agama yang mendukung Jokowi terkesan dibiarkan. Sehingga kita seringkali melaporkan, termasuk dosen UI Ade Armando itu. Kalau mau jujur itu banyak ocehan, banyak tweetnya dan tulisan-tulisan yang menghina agama dan itu sudah kita laporkan berkali-kali tetapi tidak di proses. Sementara, kalau dari kita (FPI) nyenggol sedikit saja langsung dipidanakan. (Wawancara penulis dengan Slamet Ma'arif, Ketua Bidang Hisbah FPI dan Ketua PA 212 pada 27 Juni 2021 via Zoom Meeting).

FPI memandang ada perlakuan yang berbeda ketika oposisi melakukan tindakan tersebut. FPI juga mengklaim bahwa pemerintahan Jokowi telah mengkriminalisasi HRS atas kasus chat porno.
Kriminalisasi terhadap ulama yang pernah dilakukan atas kasus tersebut dianggap tidak memiliki bukti kuat, sehingga proses penyedikannya tidak dilanjutkan. Namun, berdasarkan hasil penelitian dari SMRC yang dilakukan pada 28 Februari-8 Maret 2021 didapatkan hasil bahwa sebanyak 60 persen (dari 1064 responden) yang beragama Islam tidak percaya bahwa pemerintah telah melakukan tindakan kriminalisasi ulama dan membatasi dakwah ulama (SMRC, 2021).

\subsection{Democrazy Ekonomi}

FPI melihat bahwa democrazy ekonomi yang terjadi di masyarakat Indonesia adalah democrazy kesenjangan dan pemiskinan (Syihab, 2013, hal. 110-111). Democrazy kesenjangan telah menciptakan sebuah kondisi ekonomi dimana orang kaya akan semakin kaya dan orang miskin akan semakin miskin. Data Tim Nasional Percepatan Penanggulangan Kemiskinan (TNP2K) pada tahun 2019 menyatakan bahwa 1 persen orang kaya di Indonesia menguasai 50 persen aset nasional. Meskipun tingkat kemiskinan sejak 2015 dapat ditekan namun kesenjangan masih terjadi. Pengihitungan data ini didasari atas ketimpangan akses kebutuhan dasar (Adyatama, 2019). Hal ini disebabkan oleh lapangan pekerjaan yang tidak merata dan sulitnya mencari pekerjaan. Jika melihat data di bawah ini, maka data tingkat pengangguran di Indonesia adalah sebagai berikut:

\section{Gambar 3.1: Data Pengangguran di Indonesia} Tahun 2014-2020

Jumlah pengangguran, 2014-2020

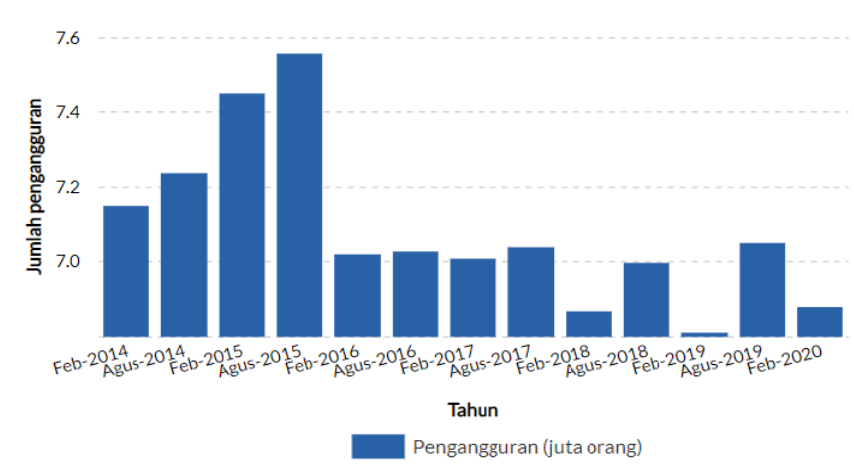

Sumber: (Lokadata, 2020)

Data tersebut diambil berdasarkan jumlah penduduk yang telah berusia lebih dari 15 tahun yang tidak memiliki pekerjaan. Pada 2014 pengangguran 7,24 juta orang; tahun 2015 berjumlah 7,56 juta orang; tahun 2016 berjumlah 7,03 juta orang; tahun 2017 berjumlah 7.04 juta orang; tahun 2018 berjumlah 7 juta orang; tahun 2019 berjumlah 7,05 juta orang dan tahun 2020 berjumlah 6,88 juta. Berarti jika dibandingkan dengan jumlah penduduk maka tingkat pengangguran hampir mencapai 3 persen. Pada 
awal kepemimpinan Jokowi di 2014 sampai dengan 2015 terlihat kenaikan jumlah pengangguran yang cukup signifikan. Kemudian, ketika 2016 jumlahnya menurun drastis. Dalam hal ekonomi Syahrozi menganggap saat ini bukan hanya lapangan pekerjaan yang menjadi persoalan serius, utang Indonesia juga menjadi problem yang harus diperhatikan, ia mengatakan sebagai berikut:

"Ekonomi kita sudah dirusak juga (oleh Jokowi), bagaimana mau diberkahi Indonesia ini, kita saja suka riba. Dengan nambah-nambah utang, yang dibayar bukan utangnya tetapi hanya bunganya. Itu lah riba, makanya tidak berkah Indonesia. Dari mulai bangun tidur sampai mau tidur lagi, itu tidak ada cerita bagus tentang Indonesia", (Wawancara penulis dengan Syahrozi, Ketua Sekretariat FPI pada 29 Juni 2021 di Majelis Ta'lim Pamulang).

Perkataan Syahrozi tersebut relevan dengan data berikut, dimana Jokowi selama masa kepemimpinannya telah mengajukan pinjaman sebesar Rp. 3.148 per Oktober 2020. Jumlah ini jauh lebih besar dari jumlah pinjaman SBY yang merupakan Presiden Indonesia sebelum Jokowi, yakni sebesar Rp. 1.309 Triliun dengan total utang Rp. 2.375,5 Triliun.

\section{Gambar 3.2: Data Utang Indonesia 2014-2020}

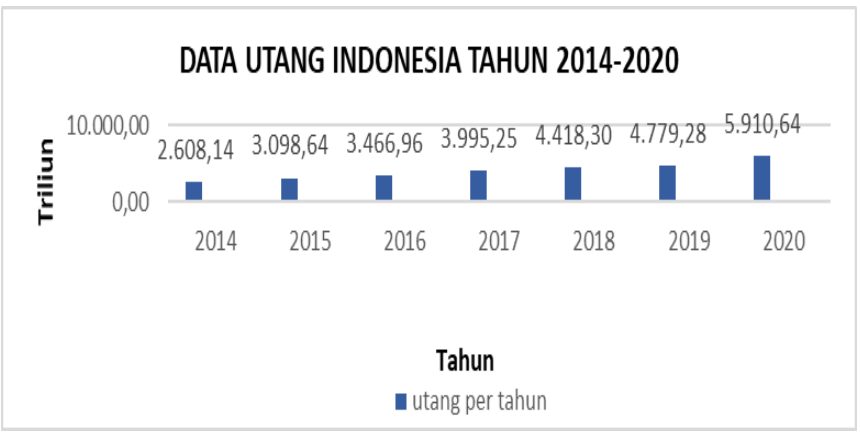

Data diolah penulis Sumber: Damayanti, 2021

Selama pemerintahan Jokowi jumlah hutang negara terus meningkat sejak 2014. Pada awal masa kepemimpinan di tahun 2014, Jokowi dibebankan utang negara oleh pemerintahan SBY sebesar Rp. 2.601,16 Triliun per Oktober 2014. Di awal kepemimpinan, saat bulan November utang tersebut beertambah menjadi Rp. 2.608,14 Triliun. Kemudian sampai saat akhir tahun 2020, utang Indonesia telah mencapai Rp. 5.910,64 Triliun. Kondisi ini menjadi perhatian dari FPI bahwa kepemimpinan Jokowi dianggap telah merusak sektor ekonomi.

Democrazy pemiskinan, dimana negara memiliki sumber daya alam tetapi masih mengandalkan impor dari negara lain, akhirnya rakyat harus membayar mahal untuk membeli barang impor tersebut.

\section{Gambar 3.3 Perbandingan Ekspor dan Impor Indonesia}

Tahun 2014 - September 2019

Ekspor dan impor Indonesia, 2014-September 2019

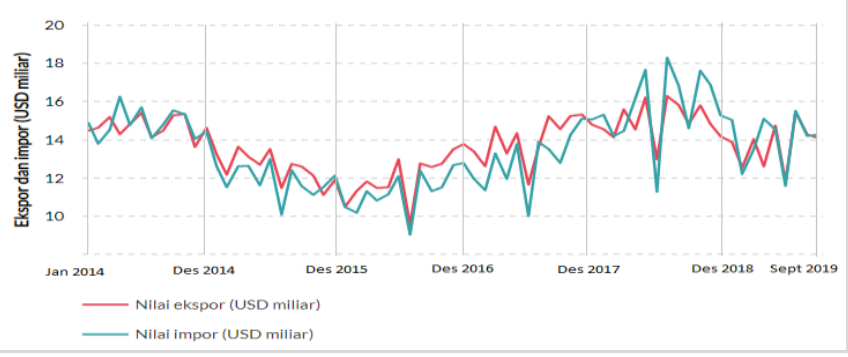

Data disesuaikan oleh penulis Sumber: (Lokadata, 2020)

Jika melihat pada data di atas, terlihat bahwa impor naik secara signifikan pada 2018 sebesar USD 18,3 Miliar, sementara nilai ekspornya adalah USD 16,29 Miliar. Terjadi penurunan nilai impor di awal 2019 menjadi USD 15,03 Miliar, sementara nilai ekspornya adalah 13,87 Miliar. Pada September 2019 angka impor kembali naik menjadi USD 14,26 Miliar. Berarti sejak 2018 sampai 2019, nilai impor lebih tinggi dari nilai ekspor. Tingginya nilai impor dibandingkan nilai ekspor menyebabkan neraca perdagangan Indonesia menjadi defisit sebanyak USD 160,5 juta.

Pandemi Covid-19 secara umum memberikan dampak buruk pada perekonomian sepanjang tahun 2020. Pertumbuhan ekonomi di saat pandemi dipengaruhi oleh daya beli masyarakat yang semakin melemah. Daya beli masyarakat menurun karena berkurangnya penghasilan karena aktivitas yang menjadi terbatas. Kemudian, karena banyak sektor yang terdampak maka kondisi ini menciptakan banyak pengangguran. Berdasarkan hasil survei Badan Pusat Statistik (BPS) pada Agustus 2020, bahwa penghasilan masyarakat menurun sebanyak 14,28 persen. Jumlah pengangguran meningkat dari 2,56 juta orang menjadi 9,77 juta orang. Dari 128,45 juta penduduk yang bekerja, jumlah pekerja pada sektor formal menurun 39,53 persen dan sektor nonformal naik sebanyak 60,47 persen (Purwanto, 2021). Artinya ketika seseorang kehilangan pekerjaan pada sektor formal, mereka memilih bekerja pada sektor non-formal.

\subsection{Democrazy Hukum}

Democrazy hukum terbagi atas democrazy keadilan dan democrazy diskriminasi (Syihab, 2013, hal. 111). Democrazy keadilan, yang mana tidak ada hukuman setimpal dan adil atas suatu kesalahan. HRS membandingkan hukum di Indonesia dengan di Arab, ketika orang mencuri dipotong tangan, sementara di Indonesia koruptor dipotong masa tahanannya. Hal ini diucapkan oleh Slamet Ma'arif sebagai berikut: 
"Ketika ada orang di rumah sakit, itu hak dia mau ngomong sakit apa atau tidak ngomong itu hak dia. HRS mengatakan "alhamdulillah saya sehat". Empat tahun di penjara, sementara yang menyuap jaksa dapat potongan hukuman dapat potongan 6 tahun jadi 4 tahun. HRS tidak pernah merampok uang negara dihukum sama dengan yang merampok uang negara. Jadi ada perlakuan yang tidak wajar", (Wawancara penulis dengan Slamet Ma'arif, 27 Juni 2021).

Pernyataan tersebut merujuk pada kasus hukum HRS, pada waktu itu HRS menolak untuk memberitahukan hasil SWAB test yang ia periksakan di RS UMMI Bogor dan menimbulkan kegaduhan. Kemudian, potongan hukuman yang dimaksudkan adalah kasus korupsi dan pencucian uang yang dilakukan Jaksa Pinangki Sirna Malasari. Pinangki diberikan potongan vonis dari 10 tahun menjadi 4 tahun masa tahanan.

Democrazy diskriminasi, terjadinya diskriminasi terhadap sesuatu yang benar dan pembenaran terhadap sesuatu yang salah. Contohnya adalah ketika Ormas melakukan salah maka organisasinya yang salah, tetapi ketika partai politik atau pejabat yang bersalah maka itu dianggap sebagai kesalahan oknum saja. HRS membandingkan sistem hukum di Indonesia dengan sistem hukum yang dibangun oleh Nabi Muhammad SAW. Ia melihat bahwa hukum di Indonesia cenderung diskriminatif. Bagi HRS, kebobrokan hukum di Indonesia bersumber pada kebobrokan sistem hukum yang ada, meskipun ditegakan oleh aparat yang baik sebab hukum sipil dianggap menyisakan banyak persoalan dan melahirkan persoalan baru di tengah kehidupan masyarakat.

\section{Latar Belakang Politis}

Selain permasahan yang disebutkan pada sub bab mengenai latar belakang ideologis, sikap oposisi FPI juga dilandasi oleh latar belakang politis dimana FPI memiliki konflik berkepanjangan dengan pemerintahan Jokowi. Pada saat diwawancarai Syahrozi membenarkan bahwa sikap oposisi FPI dilatar belakangi oleh motif politik sebab menurutnya berpolitik adalah suatu kewajiban dalam Islam. Bagi FPI keberadaan agama di dalam negara tidak dapat dipisahkan, ketika agama dipisahkan dari kehidupan bernegara maka akan menimbulkan kekacauan baik dalam pemerintahan maupun di masyarakat.

Pasca gagalnya Ahok mengikuti peoses Pilgub DKI 2017 secara penuh, FPI percaya bahwa tekanan yang diberikan pemerintah terhadap FPI adalah atas dasar dendam politik. Dengan demikian, maka penulis mengelompokan konflik yang bersinggungan langsung antara FPI dan pemerintahan Jokowi yang disebabkan oleh konflik politik, penulis jelaskan seperti di bawah ini.

\subsection{Kriminalisasi Ulama}

FPI mengatakan bahwa alasan mereka lebih intensif dalam melakukan oposisi terhadap pemerintahan Jokowi salah satunya adalah tindakan dari rezim yang sering kali mengkriminalisasi ulama. Makna kriminalisasi ulama ini merujuk pada upaya penolakan dari pihak tertentu terhadap ulama dengan upaya mengkriminalkan ulama.

Aksi FPI pada 212 mengakibatkan kalahnya Ahok di Pilgub DKI 2017. Atas permasalahan ini, timbul ketegangan yang cukup intens antara FPI dengan Pemerintah. Menurut Masduki Duryat dalam bukunya yang berjudul "Islam Majemuk" menerangkan bahwa fenomena kriminalisasi ulama secara tidak langsung telah membangun populisme Islam untuk melawan pemerintahan (Duryat, 2018). Berikut ini adalah kasus kriminalisasi ulama yang terjadi kepada HRS selaku Imam Besar FPI selama masa pemerintahan Jokowi:

\section{Tabel 3.1: Kasus Kriminalisasi Ulama}

\begin{tabular}{|c|c|c|c|}
\hline WAKTU & PERMASALAHAN & PELAPOR & KET. \\
\hline \multicolumn{4}{|c|}{ Kasus Sebelum Pelaksanaan Pilgub DKI 2017} \\
\hline $\begin{array}{l}27 \text { Oktober } \\
2016\end{array}$ & $\begin{array}{l}\text { Penodaan Pancasila } \\
\text { Perkataan HRS yang } \\
\text { berbunyi “Pancasila } \\
\text { Soekarno ketuhanan ada di } \\
\text { pantat, sedangkan } \\
\text { Pancasila Piagam Jakarta } \\
\text { ketuhanan ada di kepala. }\end{array}$ & $\begin{array}{l}\text { Sukmawati } \\
\text { Soekarnoputri }\end{array}$ & $\begin{array}{l}\text { Kasus } \\
\text { dihentikan di } \\
2018, \text { sebab } \\
\text { dianggap } \\
\text { bukan tindak } \\
\text { pidana. }\end{array}$ \\
\hline $\begin{array}{c}26 \\
\text { Desember } \\
2016\end{array}$ & $\begin{array}{l}\text { Penodaan Agama } \\
\text { Ujaran pada saat } \\
\text { berdakwah yang } \\
\text { menyebutkan "kalau Tuhan } \\
\text { beranak, siapa bidannya?" } \\
\text { yang dilakukan di Pondok } \\
\text { Kelapa. }\end{array}$ & $\begin{array}{l}\text { Perkumpulan } \\
\text { Mahasiswa } \\
\text { Katolik } \\
\text { Indonesia } \\
\text { (PMKRI) }\end{array}$ & $\begin{array}{l}\text { Tidak diketahui } \\
\text { kelanjutan dari } \\
\text { kasus ini. }\end{array}$ \\
\hline $\begin{array}{l}19 \text { Januari } \\
2016\end{array}$ & $\begin{array}{l}\text { Penguasaan Tanah Ilegal } \\
\text { Penguasaan tanah di Mega } \\
\text { Mendung, Cisarua yang } \\
\text { dijadikan pondok } \\
\text { pesantren dan Markaz } \\
\text { Syariah FPI }\end{array}$ & $\begin{array}{l}\text { Warga dengan } \\
\text { inisial E }\end{array}$ & Masih berlanjut \\
\hline $\begin{array}{c}26-30 \\
\text { Desemeber } \\
2016,8 \\
\text { Januari } \\
2017\end{array}$ & $\begin{array}{l}\text { Ujaran Kebencian } \\
\text { HRS menyinggung mata } \\
\text { uang berlogo palu arit dan } \\
\text { mengatakan bahwa Jokowi } \\
\text { adalah komunis }\end{array}$ & $\begin{array}{l}\text { Forum } \\
\text { Pemuda } \\
\text { Mahasiswa } \\
\text { Lintas Agama, } \\
\text { Perkumpulan } \\
\text { Mahasiswa } \\
\text { Katolik } \\
\text { Indonesia } \\
\text { (PMKRI), } \\
\text { Student Peace } \\
\text { Indonesia }\end{array}$ & $\begin{array}{l}\text { Tidak ada } \\
\text { kelanjutan atas } \\
\text { pelaporan. }\end{array}$ \\
\hline $\begin{array}{l}9 \text { Januari } \\
2017\end{array}$ & $\begin{array}{l}\text { Pelecehan Profesi Hansip } \\
\text { Ucapan HRS yang } \\
\text { mengatakan "pangkat } \\
\text { jendral otak hansip, sejak } \\
\text { kapan jendral bela palu- } \\
\text { arit, jangan-jangan ini } \\
\text { jendral gak lolos Litsus" }\end{array}$ & Edie Soetono & $\begin{array}{l}\text { Tidak diketahui } \\
\text { kelanjutan dari } \\
\text { kasus ini. }\end{array}$ \\
\hline $\begin{array}{c}10 \text { Januari } \\
2017\end{array}$ & $\begin{array}{l}\text { Ujaran Kebencian } \\
\text { HRS telah menyinggung } \\
\text { logo mata uang Indonesia }\end{array}$ & $\begin{array}{l}\text { Solidaritas } \\
\text { merah putih }\end{array}$ & $\begin{array}{l}\text { Tidak diketahui } \\
\text { kelanjutan dari } \\
\text { kasus ini. }\end{array}$ \\
\hline 25 Januari & $\begin{array}{l}\text { Pelecehan terhadap } \\
\text { Bahasa Sunda } \\
\text { HRS mengucapkan }\end{array}$ & $\begin{array}{l}\text { Dyna Ahmad } \\
\text { (Wakil Ketua } \\
\text { Badan }\end{array}$ & $\begin{array}{l}\text { Tidak ada } \\
\text { kabar dari } \\
\text { kelanjutan }\end{array}$ \\
\hline
\end{tabular}




\begin{tabular}{|c|c|c|c|}
\hline & $\begin{array}{l}\text { "sampurasun" menjadi } \\
\text { "campur racun" }\end{array}$ & $\begin{array}{l}\text { Musyawarah } \\
\text { Budaya } \\
\text { Sunda), Ari } \\
\text { Mulila } \\
\text { Subagja } \\
\text { (Ketua Dewan } \\
\text { Keratuan } \\
\text { Adat Sunda) }\end{array}$ & kasus ini. \\
\hline $\begin{array}{l}30 \text { Januari } \\
2017\end{array}$ & $\begin{array}{l}\text { Balada Cinta Rizieq } \\
\text { Kasus chat yang } \\
\text { mengandung pornografi } \\
\text { yang tersebar di situs: } \\
\text { www.baladacintarizieq.com }\end{array}$ & $\begin{array}{l}\text { Jefri Azhar } \\
\text { (Mahasiswa } \\
\text { Aliansi Anti- } \\
\text { Pornografi) }\end{array}$ & $\begin{array}{l}\text { Fierza Husein } \\
\text { ditetapkan } \\
\text { sebagai } \\
\text { tersangka pada } \\
\text { Mei 2017. Pada } \\
2018 \\
\text { penyelidikan } \\
\text { dihentikan. }\end{array}$ \\
\hline 2017 & $\begin{array}{l}\text { Video ujaran kebencian dan } \\
\text { dukungan kepada ISIS saat } \\
\text { HRS melakukan dakwah } \\
\text { yang diunggal melalui kanal } \\
\text { Youtube berjudul "Sikap } \\
\text { Imam Besar FPI terhadap } \\
\text { ISIS" diunggah pada } 17 \\
\text { Agustus } 2014\end{array}$ & PMKRI & $\begin{array}{l}\text { Tidak diketahui } \\
\text { kelanjutan dari } \\
\text { kasus ini. }\end{array}$ \\
\hline $\begin{array}{l}30 \text { Januari } \\
2017\end{array}$ & $\begin{array}{l}\text { Ujaran Kebencian } \\
\text { Ujaran yang menyinggung } \\
\text { masyarakat Bali }\end{array}$ & $\begin{array}{l}\text { Patriot } \\
\text { Garuda } \\
\text { Nusantara } \\
\text { (PGN) }\end{array}$ & $\begin{array}{l}\text { Tidak diketahui } \\
\text { kelanjutan dari } \\
\text { kasus ini. }\end{array}$ \\
\hline \multicolumn{4}{|c|}{ Kasus Setelah Pelaksanaan Pilgub DKI 2017} \\
\hline $\begin{array}{l}\text { November } \\
2020\end{array}$ & $\begin{array}{l}\text { Kerumunan } \\
\text { Megamendung } \\
\text { Pelanggaran Prokes pada } \\
\text { acara peletakan batu } \\
\text { pertama Pesantren } \\
\text { Agrikultural Markaz } \\
\text { Syariah }\end{array}$ & $\begin{array}{l}\text { Agus } \\
\text { Ridhallah } \\
\text { (Kasatpol PP } \\
\text { Kabupaten } \\
\text { Bogor) }\end{array}$ & $\begin{array}{l}\text { HRS didenda } \\
\text { Rp. } 20 \text { juta dan } \\
\text { subsider } 5 \\
\text { bulan penjara }\end{array}$ \\
\hline $\begin{array}{l}\text { November } \\
2020\end{array}$ & $\begin{array}{l}\text { Kerumunan Petamburan } \\
\text { III } \\
\text { Pelanggaran Prokes pada } \\
\text { acara pernikahan anak HRS } \\
\text { dan acara Maulid Nabi }\end{array}$ & & $\begin{array}{l}\text { HRS didenda } \\
\text { Rp. } 50 \text { juta; } \\
\text { Pencopotan } \\
\text { Irjen Rudy } \\
\text { Sufahradi } \\
\text { selaku Kapolda } \\
\end{array}$ \\
\hline 2021 & $\begin{array}{l}\text { Kasus Swab Test RS UMMI } \\
\text { Pelanggaran Prokes atas } \\
\text { penyebaran berita bohong } \\
\text { yang menyebabkan } \\
\text { keonaran. }\end{array}$ & $\begin{array}{l}\text { Bima Arya } \\
\text { (Ketua Satgas } \\
\text { Covid-19 Kota } \\
\text { Bogor) }\end{array}$ & $\begin{array}{l}\text { Kepala RS } \\
\text { UMMI divonis } 1 \\
\text { tahun penjara; } \\
\text { Pencopotan } \\
\text { Irjen Rudy } \\
\text { Sufahradi } \\
\text { selaku Kapolda } \\
\text { Jawa Barat; } \\
\text { HRS divonis } 4 \\
\text { tahun penjara }\end{array}$ \\
\hline
\end{tabular}

Sumber: Velarosdela, 2020 (Gual, 2017),

(Ramadhan F. M., 2018)

Kasus penodaan Pancasila dan Balada Cinta Rizieq membuat kondisi FPI saat itu tidak stabil, sehingga HRS memutuskan untuk umrah dan akhirnya menetap hingga tahun 2020 di Arab Saudi. Jika melihat data di atas, dari keseluruhan kasus, kasus yang telah mendapat vonis atau kepastian hukum adalah kasus pelanggaran Prokes.

Saat menghadiri pertemuan bersama relawan Bravo-5 pada masa kampanye Pilpres 2019, Jokowi menyatakan bahwa ketika ada ulama yang terkena kasus hukum, seringkali dirinya dikaitkan dan disebut telah mengkriminalisasi ulama "Sekarang tanyakan siapa ulama yang didiskriminasi? Ya, kalau si ini (merujuk pada HRS) ya karena memang sedang ada masalah hukum. Ini tidak logis" ucap Jokowi (CNN Indonesia, 2018). Namun, bagi tim pengacara HRS kasus kriminalisasi ulama tersebut adalah suatu upaya pemerintah untuk mengkriminalisasi HRS, hal ini sangat bernuansa politis karena pelaporannya dilakukan menjelang dan pasca Pilkada 2017.

\subsection{Polemik Kepulangan HRS ke Indonesia}

Mengutip buku yang ditulis oleh Tim Pengawal Peristiwa Pembunuhan (TP3) Enam Pengawal HRS (2021) selanjutnya penulis sebut TP3, dijelaskan bahwa kepulangan HRS ini memiliki kaitan erat dengan konflik yang terjadi setelahnya yakni penembakan enam aktivis FPI, pembubaran FPI dan penangkapan pengurus DPP FPI. Pada masa pengasingan HRS di Arab Saudi, terdapat upaya rekonsiliasi dari pemerintah yang diwakili oleh Pimpinan Intelejen RI dengan mengadakan pertemuan di Jeddah. Kemudian, Amin Rais (Ketua Dewan Pertimbangan PAN) dan Prabowo (Ketua Partai Gerindra) berkunjung untuk menemui HRS pada 2 Juni 2019. Setelah pertemuan tersebut HRS mengalami beberapa masalah hukum seperti kasus visa palsu dan pemasangan bendera ISIS. Ketika proses kepulangan, terjadi pembatalan atas tiket pesawat HRS dan keluarga. TP3 menggap bahwa upaya ini dilakukan agar HRS tidak dapat terlibat langsung dalam Pilpres 2019 (TP3, 2021, hal. 25).

Lebih lanjut TP3 menjelaskan, Agus Maftuh selaku Dubes RI untuk Saudi Arabia memberikan tiga syarat agar HRS bisa kembali ke Indonesia: 1) bersikap kooperatif dengan perwakilan RI di Arab Saudi dan menyampaikan masalah yang HRS hadapi selama di Arab; 2) mencabut pernyataan HRS yang menyebutkan bahwa Jokowi adalah presiden illegal; 3) mencabut sumpah terkait FPI tidak akan meminta bantuan pemerintah sebab pemerintahan Jokowi telah zalim.

Saat HRS tiba di Indonesia pada 10 November 2020, ia disambut oleh ribuan massa. Di tengah pandemi Covid-19, ribuan massa tersebut berkumpul mengiringi mobil yang membawa HRS menuju ke kediaman HRS. Berdasarkan pemberitaan, sejumlah massa tersebut mengabaikan protokol kesehatan dan menyebabkan beberapa kerusakan di Bandara Internasional Soekarno-Hatta (Soebijoto, 2020), (Setiawan R., Rizieq Shihab Pulang \& Potensi Munculnya Klaster Besar Corona, 2020).

Mengacu pada imbauan Kementerian Kesehatan bahwa WNI yang tiba dari luar negeri wajib melakukan karantina mandiri selama 14 hari, menjaga jarak, dan mengenakan masker. Setiap WNI wajib mengisi surat kuning tentang Riwayat perjalanan dan kondisi kesehatan terakhir. Tatapi Sugito Atmo selaku Ketua Bidang Advokasi FPI mengatakan bahwa HRS tidak akan mejalani isolasi mandiri, tetapi kalau memang ketentuannya harus melakukan SWAB PCR maka HRS dipastikan tidak akan menolak (Setiawan R., Rizieq Shihab Pulang \& Potensi Munculnya Klaster Besar Corona, 2020). 
Setelah sampai di kediamannya, HRS menerima sejumlah tokoh elite politik, diantaranya (TribunNews, 2020): 1) Anies Baswedan, Tengku Zulkarnain dan tertanggal 10 November 2020; 2) Amien Rais tertanggal 11 November 2020; 3) Elite PKS yang terdiri dari Ahmad Syaikhu, Habib Salim Segaf Al Jufri, Ahmad Heryawan dan Aboe Bakar Al Habsyi. Tujuan dari pertemuan tersebut adalah menyambut kedatangan HRS ke Indonesia, PKS juga menyampaikan bahwa PKS siap birsinergi untuk mewujudkan revolusi akhlak bangsa. Hal ini didasari atas perkataan HRS saat kepulangannya dari bandara menuju kediamannya sebagai berikut: "Saya ingin berkumpul kembali dengan umat Islam di Indonesia. Ingin berjuang bersama-sama. Saya menyerukan kepada seluruh umat Islam di Indonesia, ayo sama-sama revolusi akhlak. Revolusi akhlak akan menyelamatkan NKRI", (TribunNews, 2020).

Pada 13 November 2020, HRS menghadiri Maulid Nabi yang diselenggarakan oleh Majelis Al Afaf di Tebet, selanjutnya HRS melakukan peletakan batu pertama untuk meresmikan Pesanteren Agrikultural Markaz Syariah di Sentul. Selama perjalanannya melintasi daerah Cisarua Bogor, HRS disambut oleh ribuan warga yang berkerumun. Kemudian, HRS di kediamannya menggelar pesta pernikahan putrinya (Syarifah Najwa Syihab) pada 14 November 2020. Pesta tersebut mengundang 1000 tamu undangan.

Penyelenggaraan acara ini mengakibatkan dicopotnya Sukana selaku Kepala KUA Tanah Abang karena dianggap mengabaikan protokol kesehatan yang diatur melalui surat edaran Dirjen Bimas Kemenag. ${ }^{1}$ Setelah pelaksanaan pesta pernikahan, malam harinya dilaksanakan acara Maulid Nabi di Markaz FPI Petamburan III. Acara tersebut diselenggarakan untuk umum, sehingga diperkirakan tamu yang hadir mencapai 10.000 orang.

Ketua Satgas Covid-19 Kota Bogor pada tanggal 26 November 2021 mendapat laporan dari

1 Surat Edaran Direktur Jendral Bimbingan Masyarakat Kementerian Agama RI Nomor: P006/DJ.III/Hk.00.7/06/2020 tentang Pelayanan Nikah Menuju Masyarakat Produktif Aman Covid, maksud dan tujuan dari surat edaran ini ialah untuk mencegah dan mengurangi resiko penyebaran wabah Covid-19, melindungi pegawai KUA kecamatan dan masyarakat pada saat pelaksanaan tatanan normal baru. Pada poin 5 dan 6 diatur bahwa peserta prosesi akad nikah yang dilaksanakan di KUA atau di rumah diikuti sebanyakbanyaknya 10 orang. Prosesi akad nikah yang dilakukan di masjid atau gedung pertemuan, hanya $20 \%$ dari kapasitas ruangan dan tidak boleh lebih dari 30 orang. Kemudian, jika poin tersebut tidak terpenuhi maka penghulu wajib menolak pelayanan nikah disertai dengan alasan penolakan secara tertulis.
RS UMMI Bogor bahwa ada pasien atas nama Muhammad Rizieq Shihab. Kemudian, malam hari dilakukan tetapi bukan oleh Satgas melainkan dokter pribadi dari Mer-C. Dalam hal ini pihak Satgas tidak mendapatkan infomasi yang jelas terkait hasil swab yang telah dilakukan, maka Satgas hendak melakukan swab ulang. Tawaran ini ditolak oleh anggota keluarga HRS, Hanif Al Athos sebab sebelumnya sudah dilakukan tes. Alasan keinginan Satgas untuk melakukan swab ulang, karena menurut hasil penelusuran ditemukan 34 orang positif covid pada kluster Petamburan. Atas dasar tersebut Satgas Covid-19 Kota Bogor melaporkan hal ini kepada yang berwajib (CNN Indonesia, 2020).

\subsection{Penembakan Laskar FPI}

Penembakan Laskar FPI atau disebut juga sebagai Peristiwa KM 50 merupakan kasus penembakan terhadap 6 orang aktivis FPI, Laksar FPI DKI Jakarta. Korban dalam peristiwa tersebut adalah (TP3, 2021): 1) Lutfi Hakim (25 tahun), 2) Andi Oktavian (33 tahun), 3) Muhammad Suci Khadavi Poetra (21 tahun), 4) Faiz Ahmad Syukur (22 tahun), 5) Ahmad Sofyan alias Ambon (26 tahun), 6) Muhammad Reza (20 tahun). Dilansir melalui Repiblika.co.id, Komnas HAM berpendapat bahwa eksekusi mati atas 4 orang Laskar FPI sebagai pelanggaran HAM. Muhammad Choirul Anam dalam rekomendasinya mengatakan bahwa eksekusi mati terhadap lascar FPI sebagai bentuk unlawfull killing atau perampasan hak hidup oleh penegak hukum secara berlebihan. Meskipun 2 korban lainnya (Faiz dan Andi) tewas karena peluru tajam, tetapi Komnas HAM tidak memasukan korban sebagai korban pelanggaran HAM (Noroyono, 2021).

Usai penyelidikan, pada April 2021 Kepolisian menetapkan tiga anggota Polda Metro Jaya sebagai tersangka, namun salah satu dari tersangka tersebut telah meninggal dunia, sehingga hanya dua orang yang akan di proses hukum. Saat ini kedua anggota tersebut dibebastugaskan untuk proses penyelidikan. Mereka dikenakan Pasal 338 juncto 351 KUHP tentang pembunuhan dan penganiayaan. Namun, sampai saat ini FPI belum mengetahui identitas pelaku sebab belum dibuka kepada publik oleh Kepolisian.

Adapun terkait penyelesaian kasus penembakan tersebut, FPI berpendapat bahwa mereka sadar, penyelesaian dan penegakan keadilan atas kasus ini akan sulit didapat. Mereka menjelaskan sebagai upaya penegakan keadilan FPI telah melaporkan kasus ini ke Mahkamah Internasional atas pelanggaran HAM berat. TP3 dalam bukunya menjelaskan bahwa pembunuhan terhadap 6 Laskar FPI merupakan puncak dari 
gabungan operasi intelejen yang bermotif politik, tujuannya adalah untuk menjinakan aspirasi politik dari kelompok yang bertentangan dengan rezim (TP3, 2021).

\subsection{Pembubaran FPI}

Berdasarkan Surat Keputusan Bersama $(\mathrm{SKB})^{2}$ yang dibacakan oleh Mahfud MD, menyebutkan bahwa FPI belum memenuhi syarat untuk memperbaharui Surat Keterangan Terdaftar (SKT) sebagai Ormas yang berlaku sampai dengan tanggal 29 Juni 2019, sehingga secara dejure terhitung mulai tanggal tersebut FPI dianggap bubar. Dalam surat tersebut dinyatakan bahwa berdasarkan hasil temuan terdapat anggota FPI ataupun yang pernah bergabung di FPI sebanyak 35 orang terlibat tindak pidana terorisme, 29 orang daintaranya telah dijatuhi pidana. Sebanyak 206 orang terlibat tindak pidana umum, 100 orang diantaranya sudah dijatuhi hukuman pidana. Berkenaan dengan SKB, Mahfud MD menjelaskan bahwa FPI tidak lagi memiliki legal standing, baik sebagai Ormas maupun organiasi biasa (Habibie, 2020).

Dalam hal ini Syahrozi menjelaskan alasan mengapa pemerintah mengatakan pembekuan bukan pembubaran, sebab jika membubarkan suatu Ormas harus melalui proses persidangan melalui PTUN. Sidang PTUN legal apabila FPI memiliki izin, sehingga dalam hal ini FPI menimbang untuk tidak memperpanjang izin dan memilih untuk membentuk Front Persaudaraan Islam (sebelumnya: Front Persatuan Islam). Hal ini juga dijelaskan oleh Irbabul Lubab sebagai berikut:

"Kebebasan berserikat dan berkumpul adalah hak yang dilindungi undang-undang, bagi anggota FPI organisasi FPI adalah sebuah kendaraan. Ketika kendaraan tersebut sudah tidak dapat digunakan, maka kita pakai kendaraan baru. Kendaraan baru ini yang akan mengantarkan kita mencapai tujuan untuk menegakan ajaran Islam". (Wawancara penulis dengan Irbabul Lubab, 23 Mei 2021).

2 Surat Keputusan Bersama No. 220-4780 Tahun 2020, No. M.HH-14.HH.05 Tahun 2020, No. 690 Tahun 2020, No. 264 Tahun 2020, No. KB/3/XII/2020, No, 320 Tahun 2020 tertanggal 30 Desember 2020 tentang larangan kegiatan, penggunaan simbol dan atribut serta penghentian kegiatan Front Pembela Islam. Surat ini ditandatangani oleh 6 institusi, yakni: 1) Muhammad Tito Karnavian selaku Menteri Dalam Negeri RI; 2) Yasonna H. Laoly selaku Menteri Hukum dan HAM RI; 3) Johnny G. Plate selaku Menteri Komunikasi dan Informatika RI; 4) Burhanuddin selaku Kejaksaan Agung RI; 5) Jendral Pol. Idham Aziz selaku Kepala Kepolisian Negara RI; 6) Boy Rafli Amar selaku Kepala Badan Penanggulangan Terorisme RI.
Jadi dapat disimpulkan bahwa alasan FPI tidak memperpanjang SKT adalah: Pertama, sudah mengupayakan pengurusan SKT, namun tidak ada kesepemahaman. Kedua, ketika dikeluarkan SKB perizinan yang dimiliki FPI dapat menjadi alat legal bagi pemeuntuk membubarkan FPI.

Di hari yang sama dengan pembacaan SKB terjadi penurunan atribut FPI di Markaz FPI dan sekitar Markaz FPI. Kegiatan ini dilakukan oleh tim gabungan Brimob dan TNI. Pada saat itu terdapat 7 orang yang diamankan dan dibawa ke Polda Metro Jaya untuk diperiksa dan dimintai keterangan. Selanjutnya setelah penangkapan Munarman selaku sekretaris FPI tertanggal 7 April 2021, Tim Datasemen Khusus (Densus 88) melakukan penggeledahan Markaz FPI. Kemudian, ditemukan dugaan adanya bahan peledak yang disimpan di Markaz FPI Peramburan. Berdasarkan pengamatan Syahrozi ia menyimpulkan bahwa sebenarnya barang bukti terkait adanya bahan peledak tidak mendasar. Penggeledahan ini hanya sebuah prakondisi untuk penangkapan HRS dan Munarman, sebab hingga saat ini dugaan terkait terorisme belum berlanjut.

\subsection{Penangkapan Anggota FPI}

Berkenaan dengan kasus kerumunan yang dilakukan, HRS menyerahkan diri pada Kepolisian pada 12 Desember 2020. Kemudian dilakukan penahanan selama 20 hari hingga 31 Desember 2020 (satu hari setelah terbit SKB). Penyerahan diri tersebut bersamaan dengan penyerahan diri Haris Ubaidilah, Habib Idrus dan Habib Ali bin Alwi Alatas. Ahmad Shabri Lubis dan Maman Suryadi akhirnya menyerahkan diri setelah diberi ultimatum oleh Kombes Pol Yusri Yunus, Kabid Humas Polda Metro Jaya "Dua opsi yang kami berikan: menyerahkan diri atau akan kami tangkap", (Setiawan R. , 2020). Berikut ini adalah penjelasan kasus hukum anggota FPI, pasca kepulangan HRS ke Indonesia:

Tabel 3.3: Kasus Anggota FPI

\begin{tabular}{|c|c|c|c|}
\hline TANGGAL & KASUS & PASAL & KETERANGAN \\
\hline \multirow[t]{2}{*}{$\begin{array}{c}12 \text { Desember } \\
2020 \\
\text { (menyerahkan } \\
\text { diri) }\end{array}$} & $\begin{array}{l}\text { HRS } \\
\text { Kasus hasil } \\
\text { SWAB di RS } \\
\text { UMMI Bogor }\end{array}$ & $\begin{array}{l}\text { Pasal } 14 \text { Ayat } 1 \text { UU } \\
\text { No. } 1 \text { Tahun } 1946 \\
\text { Peraturan Hukum } \\
\text { Pidana tentang } \\
\text { Peraturan Hukum } \\
\text { Pidana Junco Pasal } \\
55 \text { Ayat } 1 \text { KUHP } \\
\text { Ke-1 KUHP }\end{array}$ & $\begin{array}{l}\text { Pemberitahuan } \\
\text { bohong, karena } \\
\text { mengatakan } \\
\text { kondisinya sehat } \\
\text { walaupun } \\
\text { terkonfirmasi Covid- } \\
19 . \\
\text { Divonis } 4 \text { tahun } 8 \\
\text { bulan kurungan } \\
\text { penjara }\end{array}$ \\
\hline & $\begin{array}{l}\text { Haris } \\
\text { Ubaidilah } \\
\text { Ketua acara } \\
\text { Habib Ali bin } \\
\text { Alwi Alatas } \\
\text { Sekretaris } \\
\text { acara } \\
\text { Habib Idrus }\end{array}$ & $\begin{array}{l}\text { Pasal } 93 \text { UU No. } 6 \\
\text { Tahun } 2018 \\
\text { tentang } \\
\text { Kekarantinaan } \\
\text { Kesehatan }\end{array}$ & $\begin{array}{l}\text { Kerumunan } \\
\text { Petamburan dan } \\
\text { Tebet } \\
\text { Divonis } 8 \text { bulan } \\
\text { penjara }\end{array}$ \\
\hline
\end{tabular}


Kepala seksi

acara

\begin{tabular}{|c|c|c|c|}
\hline \multirow[t]{2}{*}{$\begin{array}{l}14 \text { Desember } \\
2020 \\
\text { (menyerahkan } \\
\text { diri) }\end{array}$} & $\begin{array}{l}\text { Ahmad } \\
\text { Shabri Lubis } \\
\text { Ketua FPI } \\
\text { Maman } \\
\text { Suryadi } \\
\text { Panglima FPI }\end{array}$ & $\begin{array}{l}\text { Pasal } 93 \text { UU No. } 6 \\
\text { Tahun } 2018 \\
\text { tentang } \\
\text { Kekarantinaan } \\
\text { Kesehatan }\end{array}$ & \\
\hline & $\begin{array}{l}\text { Muhammad } \\
\text { Hanif Alatas } \\
\text { Menantu HRS } \\
\text { Kasus hasil } \\
\text { SWAB di RS } \\
\text { UMMI Bogor }\end{array}$ & $\begin{array}{l}\text { Pasal } 14 \text { Ayat } 1 \text { UU } \\
\text { No. } 1 \text { Tahun } 1946 \\
\text { Peraturan Hukum } \\
\text { Pidana tentang } \\
\text { Peraturan Hukum } \\
\text { Pidana Junco Pasal } \\
55 \text { Ayat } 1 \text { KUHP } \\
\text { Ke-1 KUHP }\end{array}$ & $\begin{array}{l}\text { Pemberitahuan } \\
\text { bohong mengenai } \\
\text { kondisi Kesehatan } \\
\text { HRS dengan } \\
\text { mengatakan } \\
\text { kondisinya sehat } \\
\text { walaupun } \\
\text { terkonfirmasi Covid- } \\
19 . \\
\text { Divonis } 1 \text { tahun } \\
\text { kurungan penjara }\end{array}$ \\
\hline 27 April 2021 & $\begin{array}{l}\text { Munarman } \\
\text { Teorisme }\end{array}$ & $\begin{array}{l}\text { Pasal } 14 \text { juncto } \\
\text { pasal } 7 \\
\text { Pasal } 15 \text { juncto } \\
\text { Pasal } 7 \\
\text { Pasal } 14 \text { UU No. } 5 \\
\text { Tahun } 2018 \\
\text { tentang tindak } \\
\text { pidana teorisme }\end{array}$ & $\begin{array}{l}\text { Ancaman penjara } \\
\text { seumur hidup } \\
\text { Belum ada vonis }\end{array}$ \\
\hline
\end{tabular}

Sumber: Tim detikcom, 2021 (Bimo, 2021)

Terkait penahanan dan vonis yang diberikan kepada HRS tersebut, Slamet Ma'arif memiliki pandangan bahwa terdapat unsur politik yang sangat kuat. Vonis tersebut dimaksudkan agar HRS tidak terlibat dalam Pilpres 2024 mendatang. Hal yang sama juga diungkapkan oleh Syahrozi bahwa vonis tersebut mengandung unsur politis dan jelas ada faktor kesengajaan. Tekanan pemerintah terhadap FPI diperlihatkan pada opsi hukum yang diberikan kepada HRS. Dengan vonis hukum tersebut HRS mengambil opsi banding, FPI menolak untuk mengajukan permohonan pengampunan kepada presiden sebab HRS dan FPI merasa keberatan atas vonis tersebut. Lebih lanjut, Syahrozi menjelaskan bahwa kasus hukum HRS merupakan pengalihan isu atas kasus HAM berat, yakni penembakan 6 Laskar FPI.

\section{KESIMPULAN}

Sikap oposisi FPI terhadap pemerintahan Jokowi dilandasi oleh latar belakang ideologis dan politis. Latar belakang ideologis tidak terlepas dari pemikiran HRS sebagai pendiri FPI, pemikirannya juga menjadi landasan atas sikap dan gerakan FPI. Secara ideologis, FPI memandang bahwa demokrasi membawa efek buruk dan sumber masalah di kehidupan masyarakat secara nyata. Demokrasi telah menciptakan sistem yang korup, pemimpin diktator, yang juga menjadi penyebab perpecahan akibat dari adanya perebutan kekuasaan. Sehingga HRS menyebut demokrasi menjadi "democrazy". Democrazy sistem memungkinkan setiap orang untuk memiliki hak suara yang sama dan dianggap setara. FPI juga melihat bahwa democrazy ekonomi yang terjadi di masyarakat Indonesia adalah democrazy kesenjangan dan pemiskinan. Dimana orang kaya akan semakin kaya dan orang miskin akan semakin miskin. Democrazy secara hukum dapat dilihat ketika tidak ada hukuman setimpal dan adil atas suatu kesalahan. Diskriminasi terhadap sesuatu yang benar dan pembenaran terhadap sesuatu yang salah juga sering terjadi.

Sikap oposisi FPI juga dilandasi oleh latar belakang politis diakibatkan oleh konflik berkepanjangan dengan pemerintahan Jokowi. FPI mengatakan bahwa alasan mereka lebih intensif dalam melakukan oposisi terhadap pemerintahan Jokowi salah satunya adalah tindakan dari rezim yang sering kali mengkriminalisasi ulama. Kepulangan HRS dari Arab Saudi pada 2020 lalu, memiliki kaitan erat dengan konflik yang terjadi setelahnya yakni penembakan enam aktivis FPI, pembubaran FPI dan penangkapan pengurus DPP FPI. Berkenaan dengan vonis kasus kerumunan yang dilakukan HRS, dianggap sebagai upaya agar HRS tidak terlibat dalam Pilpres 2024 mendatang.

\section{DAFTAR PUSTAKA}

Adyatama, E. (2019, Oktober 10). Survei: 1 Persen Orang Kaya RI Kuasai 50 Persen Aset Nasional. Retrieved Agustus 2, 2021, from Tempo:

https://bisnis.tempo.co/read/1257730/sur vei-1-persen-orang-kaya-ri-kuasai-50persen-aset-nasional

Aji, M. R. (2019, November 30). Cerita Panas Dingin Hubungan FPI dengan Pemerintah. Retrieved Juni 27, 2020, from Tempo.co: https://nasional.tempo.co/read/1278349/c erita-panas-dingin-hubungan-fpi-denganpemerintah/full?view $=$ ok

Auliani, P. A. (2013, Juli 19). Ini Kronologi Bentrok Warga dengan FPI di Kendal. Retrieved Juni 27, 2020, from Kompas.com: https://regional.kompas.com/read/2013/0 7/19/0022293/Ini.Kronologi.Bentrok.Warg a.dengan.FPI.di.Kendal

Baehaqi, I. (Penyunt.). (2010). Kontroversi Aswaja: Aula Perdebatan dan Reinterpretasi. Yogyakarta: LKiS Yogyakarta.

Bimo, A. (2021, April 28). Disangkakan 2 Pasal, Munarman Terancam Hukuman Penjara Seumur Hidup. Retrieved JUne 6, 2021, from KompasTV:

https://www.kompas.tv/article/169175/dis angkakan-2-pasal-munarman-terancamhukuman-penjara-seumur-hidup

CNN Indonesia. (2018, Desember 10). Jokowi Bandingkan Isu Kriminalisasi Ulama dan Kasus Gubernur. Retrieved Maret 12, 2021, from CNN Indonesia: https://www.cnnindonesia.com/ nasional/20181210202513-32- 
352579/jokowi-bandingkan-isu-

kriminalisasi-ulama-dan-kasus-gubernur

CNN Indonesia. (2020, November 29). Kronologi

Rizieq Tes Swab Hingga RS UMMI Dipolisikan.

Retrieved Mei 3, 2021, from CNN Indonesia: https://www.cnnindonesia.com/nasional/2 0201129003010-20-575740/kronologirizieq-tolak-tes-swab-hingga-rs-ummidipolisikan

CNN Indonesia. (2020, Desember 31). Mimpi Gus Dur Bubarkan FPI Berbalas Perlawanan Rizieq Shihab. Retrieved Mei 1, 2021, from CNN

Indonesia:

https://www.cnnindonesia.com/nasional/2 0201230194303-20-588056/mimpi-gusdur-bubarkan-fpi-berbalas-perlawananrizieq-shihab

Creswell, J. W. (2017). Research Design:. (A. Fawaid, \& R. K. Pancasari, Penerj.) Yogyakarta: Pustaka Pelajar.

Dahl, R. A. (1966). Political Oppositions in Western Democracies. New Heaven and London: Yale University Press.

Damayanti, A. (2021, Juni 6). Perjalanan Utang Pemerintah Sejak Jokowi Jadi Presiden. Retrieved Juni 20, 2021, from Detik FInance: https://finance.detik.com/berita-ekonomibisnis/d-5595168/perjalanan-utangpemerintah-sejak-jokowi-jadi-presiden $/ 2$

Detikcom. (2020, November 18). Doa Jokowi-Mega Umur Pendek di Acara Maulid Dikritik, Ini Respons FPI. Retrieved Juni 16, 2021, from DetikNews:

https://news.detik.com/berita/d-

5260012/doa-jokowi-mega-umur-pendek-

di-acara-maulid-dikritik-ini-respons-fpi

Duryat, M. (2018). SLAM MAJEMUK; Pengejawantahan Pendidikan, Interpretasi dan Model Islam Keindonesiaan. Yogyakarta: K-Media.

Duverger, M. (1984). Partai Politik dan KelompokKelompok Penekan. (L. Hasyim, Penerj.) Yogyakarta: Bina Aksara.

Dzulfaroh, A. N. (2020, September 24). Hari Ini dalam Sejarah: Tragedi Semanggi II. Retrieved Juni 29, 2021, from Kompas.com: https://www.kompas.com/tren/read/2020 /09/24/125500865/hari-ini-dalam-sejarah-tragedi-semanggi-ii?page $=$ all

FaktaKini. (2019, Agustus 17). Fakta Kini. Retrieved Juni 22, 2021, from Inilah Para Deklarator Berdirinya FPI 17 Agustus 1998 Di Ponpes Al Umm Ciputat: https://www.faktakini.info/2019/08/inilahpara-deklarator-berdirinyafpi.html\#comment-form

FaktaKini. (2020, Mei 28). Habib Rizieq: Umat Islam Belanjalah Di Toko Dan Warung Muslim
Untuk Perkuat Ekonomi Umat. Dipetik Mei 17, 2021, dari https://www.faktakini.info/2020/05/habibrizieq-umat-islam-belanjalah-di.html

Firdaus, F. (2009, Juni 26). FPI Deklarasi Dukung JKWiranto. Retrieved Juli 31, 2021, from Oke News: https://news.okezone.com/read/ 2009/06/26/268/233251/fpi-deklarasidukung-jk-wiranto

Firdausi, F. A. (1999, Oktober 20). Empat Bulan Setelah Dilantik Jadi Presiden, Gus Dur Memecat Wiranto. Retrieved Juni 29, 2021, from Tirto.id: https://tirto.id/empat-bulansetelah-dilantik-jadi-presiden-gus-durmemecat-wiranto-ejdk

Gischa, S. (2020, Oktober 2). Penyebab Krisis Moneter di Indonesia. Retrieved Juni 28, 2021, from Kompas.com: https://www.kompas.com/skola/read/202 0/02/10/170000769/penyebab-krisismoneter-di-indonesia?page $=$ all

Gual, M. (2017, Juni 6). Rizieq Dilaporkan ke Polda Bali, Pengacara Sebut Politis. Retrieved Januari 14, 2021, from CNN Indonesia: https://www.cnnindonesia.com/nasional/2 0170609114818-12-220560/rizieqdilaporkan-ke-polda-bali-pengacara-sebutpolitis

Habibie, N. (2020, Desember 30). Polisi Amankan 7 Orang Saat Menurunkan Atribut FPI di Petamburan. Retrieved Februari 12, 2021, from Merdeka.com: https://www.merdeka.com/ peristiwa/ polisi-amankan-7-orang-saat-menurunkanatribut-fpi-di-petamburan.html

Heryanto, G. G. (2019). Literasi Politik. Yogyakarta: IRCISoD.

Indra, P. A. (2016, November 4). FPI dalam Lintasan Sejarah. Retrieved Maret 30, 2020, from Tirto.id: https://tirto.id/fpi-dalam-lintasansejarah-b1NT

Jahroni, J. (2004). Defending The Majesty of Islam: Indonesia's Front Pembela Islam (FPI) 19982003. Studia Islamika, 11(2).

Jurdi, S. (2016). Kekuatan-Kekuatan Politik di Indonesia. Jakarta: Kecana.

Kamil, I. (2021, April 28). Seputar Penggeledahan di Markas FPI, Temuan Bahan Berbahaya Hingga Penyegelan. Retrieved Juni 21, 2021, from Kompas.com: https://nasional.kompas.com/read/ 2021/04/28/09093561/seputarpenggeledahan-di-markas-fpi-temuanbahan-berbahaya-hinggapenyegelan?page $=$ all

Lokadata. (2020, Oktober 15). Ekspor dan impor Indonesia, 2014-September 2019. Retrieved Juni 13, 2021, from Lokadata: 
https://lokadata.id/data/ekspor-dan-imporindonesia-2014-september-2019-

1571121725

Lokadata. (2020, Juli 29). Jumlah pengangguran, 2014-2020. Retrieved Juni 13, 2021, from Lokadata: https://lokadata.id/data/jumlahpengangguran-2014-2020-1595988843

Maulaa, M. R. (2021, Januari 23). Mengenal Pam Swakarsa, dari Tragedi Semanggi 1998 hingga Digagas Ulang Kapolri Baru. Retrieved Juni 30, 2021, from PikiranRakyat.com: https://www.pikiranrakyat.com/nasional/pr-

011315515/mengenal-pam-swakarsa-daritragedi-semanggi-1998-hingga-digagasulang-kapolri-baru?page $=3$

Miles, M. B. (2014). Qualitative Data Analysis: A Methode Source Book. United State of America: SAGE Publication.

Muhtadi, B. (2019). Populisme, Politik Identitas, dan Dinamika Elektoral. Malang: Intrans Publishing.

Noroyono, B. (2021, Januari 8). Ini Kronologi Penembakan Laskar FPI Versi Komnas HAM. Retrieved Mei 13, 2021, from Republika.co.id:

https://www.republika.co.id/berita/qmmaa v409/ini-kronologi-penembakan-laskar-fpiversi-komnas-ham

Nurjannah. (2013). Faktor Pemicu Munculnya Radikalisme Islam atas Nama Dakwah. Jurnal Dakwah, Vol. XIV, No. 2, 17.

Purwanto, A. (2021, Januari 27). Ekonomi Indonesia pada Masa Pandemi Covid-19: Potret dan Strategi Pemulihan 2020-2021. Retrieved Agustus 3, 2021, from Kompaspedia: https://kompaspedia. kompas.id/ baca/paparan-topik/ekonomi-indonesiapada-masa-pandemi-covid-19-potret-danstrategi-pemulihan-2020-2021

Quraisyiah, F. (2014). Pemikiran Dakwah Habib Rizieq Syihab, MA. Jakarta: UIN Syarif Hidayatullah Jakarta.

Rahmat, M. I. (2007). Arus Baru Islam Radikal: Transmisi Revivalisme Islam Timur Tengah. Jakarta: Erlangga.

Ramadhan, F. M. (2018, Februari 23). Deretan Kasus Rizieq Shihab, 11 Tuntutan dalam 9 Bulan. Retrieved Maret 20, 2021, from Tempo.co: https://grafis.tempo.co/read/1164/deretan -kasus-rizieq-shihab-11-tuntutan-dalam-9bulan

Rizieq, H. (2011). Hancurkan Liberalisme, Tegakkan Syariat Islam. Jakarta: Suara Islam.

Setiawan, R. (2020, Desember 15). Rizieq Shihab dkk Ditangkap Polisi, FPI Bubar? Retrieved Maret 19, 2021, from Tirto.id: https:// tirto.id/rizieq-shihab-dkk-ditangkap-polisifpi-bubar-f8aY

Setiawan, R. (2020, November 9). Rizieq Shihab Pulang \& Potensi Munculnya Klaster Besar Corona. Retrieved Mei 30, 2021, from Tirto.id: https://tirto.id/rizieq-shihabpulang-potensi-munculnya - klaster- besarcorona-f6L9

SMRC. (2021, April 6). 60\% Warga Muslim Tidak Percaya Pemerintah Melakukan Kriminalisasi Ulama. Retrieved Juni 19, 2021, from Saiful Mujani Research \& Consulting: https://saifulmujani.com/ 60-wargamuslim-tidak-percaya-pemerintahmelakukan-kriminalisasi-ulama/

Soebijoto, H. (Ed.). (2020, November 14). Kepulangan Habib Rizieq Abaikan Protokol Kesehatan, Pemerintah Abai Lindungi Masyarakat saat Pandemi. Retrieved Mei 30, 2021, from Wartakota: https://wartakota.tribunnews.com/2020/1 1/16/ kepulangan-habib-rizieq-abaikanprotokol-kesehatan-pemerintah-abailindungi-masyarakat-saat-pandemi

Subarkah, M. (2018, Oktober 3). Relawan FPI Hingga Kenangan Evakuasi Mayat Tsunami Aceh. Retrieved Juli 31, 2021, from Republika.id: https://www.republika.co.id/berita/pfz2ty3 85/relawan-fpi-hingga-kenangan-evakuasimayat-tsunami-aceh

Sukmadinata, N. S. (2012). Metode Penelitian Pendidikan. Yogyakarta: Rosda.

Syihab, H. R. (2008). Dialog FPI: Amar Ma'ruf Nahi Munkar. Jakarta: Pustaka Ibnu Sidah.

Syihab, H. R. (2013). Wawasan Kebangsaan: Menuju NKRI Bersyariah. Jakarta: Suara Islam.

Tempo. (2003, Mei 18). Pagi Berdarah di Ketapang. Retrieved November 16, 2020, from Tempo.co: https://majalah.tempo.co/ read/ fotografi/ 87596/pagi-berdarah-di-ketapang

Tempo. (2003, Agustus 23). Tujuh Bulan Penjara untuk Habib Rizieq. Dipetik Desemeber 3, 2020, dari Tempo.co: https:// nasional.tempo.co/read/12476/tujuhbulan-penjara-untuk-habibrizieq/full?view $=$ ok

Tempo.co. (2003, Desember 18). FPI Ubah Paradigma Perjuangan. Retrieved Juni 30 2021, from Tempo.co: https://nasional. tempo.co/read/36179/fpi-ubah-paradigmaperjuangan

Tempo.co. (2021, Juni 7). 7 Juni, Pemilu Pertama Era Reformasi 1999 Dilaksanakan, Perolehan 5 Partai Besar. Retrieved Juni 30, 2021, from Tempo: https://nasional.tempo.co/read/1469717/7 -juni-pemilu-pertama-era-reformasi-1999- 
dilaksanakan-perolehan-5-partaibesar /full\&view=ok

Tempo.co. (2021, Mei 14). Kerusuhan Mei 1998, Sejarah Kelam Pelanggaran HAM di Indonesia. Retrieved Juni 29, 2021, from Tempo.co:

https://nasional.tempo.co/read/1462239/k erusuhan-mei-1998-sejarah-kelam-

pelanggaran-ham-diindonesia/full\&view=ok

Tim detikcom. (2021, Juni 24). Menantu Habib Rizieq Divonis 1 Tahun Penjara! Retrieved Juli 4, 2021, from Detikcom: https://news.detik.com/berita/d5618298/menantu-habib-rizieq-divonis-1tahun-penjara

Tim Pengawal Peristiwa Pembunuhan (TP3). (2021). Buku Putih Pelanggaran HAM Berat: Pembunuhan Enam Pengawal HRS. Jakarta: Yayasan Pengkajian Sumber Daya Indonesia (YPSDI).

Tim Tempo. (2003, Agustus 23). Tujuh Bulan Penjara untuk Habib Rizieq. Retrieved Desember 3, 2020, from Tempo.co: https://nasional.tempo.co/read/12476/tuju h-bulan-penjara-untuk-habibrizieq/full?view $=$ ok

TribunNews. (2020, November 12). Daftar Tokoh yang Temui Habib Rizieq Shihab di Petamburan: Anies, Amien Rais, hingga Elite PKS. Retrieved Mei 13, 2021, from TribunNews.com:

https://www.tribunnews.com/nasional/202 0/11/12/daftar-tokoh-yang-temui-habibrizieq-shihab-di-petamburan-anies-amienrais-hingga-elite-pks?page $=4$

TribunNews.com. (2020, Desember 30). Politikus PDIP: Selama Ini FPI Ganggu Stabilitas Umum dan Rugikan Orang Lain. Retrieved Agustus 4, 2021, from TribunNews.com : https://www.tribunnews.com/nasional/202 0/12/30/politikus-pdip-selama-ini-fpiganggu-stabilitas-umum-dan-rugikan-oranglain

Velarosdela, R. N. (2020, Desember 19). Deretan Kasus Hukum Rizieq Shihab, Tersangka Kasus Kerusuhan Monas hingga Kerumunan di Petamburan. Retrieved Desember 23, 2020, from Megapolitan.kompas.com: https://megapolitan.kompas.com/read/202 0/12/10/13270311/deretan-kasus-hukumrizieq-shihab-tersangka-kasus-kerusuhanmonas-hingga?page=all

Velarosdela, R. N. (2020, Desember 19). Deretan Kasus Hukum Rizieq Shihab, Tersangka Kasus Kerusuhan Monas hingga Kerumunan di Petamburan. Retrieved Desemeber 23, 2020, from https://megapolitan.kompas.com/read/202 0/12/10/13270311/deretan-kasus-hukumrizieq-shihab-tersangka-kasus-kerusuhanmonas-hingga?page $=$ all

Warsono, A. (2019, Januari 30). Yusril Persilakan Rizieq Shihab Tarik Anggota FPI dari PBB. Retrieved Juni 2, 2021, from Tempo.co: https://metro.tempo.co/read/1479311/ban yak-plang-di-lahan-ptpn-viii-catut-namarizieq-shihab-kuasa-hukum-oknum-itu

Woodward, M., \& Nurish, A. (2016, Desember). Quo Vadis FPI Dalam Aksi Bela Islam. Jurnal Ma'arif, Vol. 11, No. 2.

Yamin, H. M. (2018). Perspektif Demokrasi untuk Islam Indonesia. Yogyakarta: Deepublish.

Zada, K. (2002). Islam Radikal: Pergulatan Ormasormas Islam Garis Keras di Indonesia. Jakarta: Teraju.

Zastrow, A. (2013). Gerakan Islam Simbolik: Politik Kepentingan FPI. Yogyakarta: LKiS Yogyakarta.

Zuhri, S. (2017). Deradikalisasi Terorisme. Jakarta: Daulat Press Jakarta. 